\title{
EJSBS
}

The European Journal of Social \&

Behavioural Science

ISSN: 2301.2218 (ONUNE)
OPENACCESS

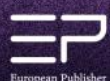

The European Journal of Social and Behavioural Sciences

EJSBS Volume XXX, Issue II (eISSN: 2301-2218)

\section{CRITERIA OF EXTREMIST SPEECH ACTS: FORENSIC LINGUISTIC DIAGNOSTIC COMPLEXES}

\author{
Nikishin Vladimir Dmitrievich ${ }^{\mathrm{a} *}$ \\ ${ }^{a}$ Department of Forensic Expertise, Kutafin Moscow State Law University, Sadovaya-Kudrunskaya Str., 9, Moscow, \\ 123001, Russia
}

\begin{abstract}
The article examines the challenges in detecting features of verbal extremism by analysing forensic practice, research papers on forensic linguistics and anti-extremist law, manuals developed by Russian law enforcement agencies and scientific and educational organizations. The article suggests a new approach to the methodological support of forensic linguistic examination of extremist discourse. This approach is based on the concept of a threecomponent structure of 'extremist' utterances. The author justifies the proposed classification of extremist speech acts and describes forensic diagnostic complexes corresponding to these speech acts. These complexes can serve as the reference samples for both linguistic experts (who conduct forensic examination) and the law enforcement officers (who conduct forensic diagnostics). The use of standardized forensic diagnostic complexes of extremist speech acts which serve as a tool for classification of illegal verbal behaviour allows to maintain the balance between the right to freedom of speech and pluralism of opinions, on the one hand, and protection against abuse of these rights (protection of media security), on the other hand.
\end{abstract}

Keywords: Forensic speech science, forensic linguistics, speech act, extremism, hate speech

C 2021 Published by European Publisher. www.europeanpublisher.com

${ }^{*}$ Corresponding author. Tel.: +7-926-855-55-29.

E-mail address: vdnikishin@gmail.com 
https://doi.org/10.15405/ejsbs.296

eISSN: 2301-2218 / Corresponding Author: Nikishin Vladimir Dmitrievich

Selection \& Peer-review under responsibility of the Editors

\section{Introduction}

The propaganda of extremist-terrorist ideology has reached unimaginable global proportions in the digital age. Such destructive propaganda threatens freedom, life and health of people, democratic society and constitutional order (the basis for every state governed by the rule of law). It is often impossible to legally describe information materials as being extremist without applying special (forensic) knowledge in the field of linguistics to this description. However, the existing forensic practice demonstrates that there is no universal approach to the definition of linguistic features of verbal extremism. Expert reports are often limited to the expression of linguists' subjective views based on their personal ethical judgments instead of conducting a scientifically based research.

The situation needs to be improved. Legal proceedings should be based on objective evidence, which means that the forensic linguistic examination should be based on clear criteria and methods which allow assessing the scientific validity of the expert's report. The result of the forensic examination should be verifiable, i.e. examination of the same object according to the same methodology should give the same result regardless of the expert's personality.

Verbal extremism can be defined as an action committed verbally and aimed at inciting hatred and enmity towards a person(s) in connection with their ethnic / religious / other social identity or at humiliation of human dignity and / or insult to religious feelings of persons in connection with their religious identity, as well as calls for extremist and / or terrorist activities (Art. art. 148, 205.2, 280, 282 of the Criminal Code of the RF, Art. 20.3.1 of the Administrative Code of the Russian Federation (RF)).

\section{Discussion}

\subsection{Speech acts theory \& verbal extremism}

The methodology related to the forensic linguistic examination of materials containing extremist discourse is based on the theory of speech acts at the current stage of development of forensic linguistics.

In 1955, John Langshaw Austin outlined the main ideas of the speech act theory in a course of lectures at Harvard, and in 1962, after his death, his ideas were published in the book 'How to do things with words' (Austin, 1962) which then were developed by John Rogers Searle (1969) and other scholars.

Subsequently, the speech acts theory became the theoretical basis of linguistic pragmatics considering the activity-oriented nature of language. 
In pragmatics, there is usually no distinction between a speech action and speech act. Their definition can be summarized as follows: an action

- performed in accordance with the principles and rules of speech behavior determined by the speaker's intention,

- performed on the basis of pronunciation (writing) formulating a certain mental content.

It should be emphasized that the purposefulness of the extremist action is its prominent feature. Its ability to encourage the addressee to a certain action by persuading, promising, threatening, etc. (Antonova, et al, 2014), and/or forming a hostile, intolerant attitude through agitation and justification of the impossibility of changing the current situation is its equally important feature.

\subsection{Types of extremist speech acts}

Five types of extremist speech actions (acts) have been distinguished based on the analysis of titles of extremist actions in legal acts, as well as the analysis of features of verbal extremism highlighted in the scientific literature, international, Russian law and national law of European states (Nikishin, 2019). Table 1 displays the types of speech acts.

Table 1. Types of extremist speech acts

\section{Types of extremist speech acts}

1. Calls for carrying out extremist activities

2. Rationale for the need to carry out extremist activities

3. Justification of the need to carry out extremist activities

\begin{tabular}{|c|}
\hline 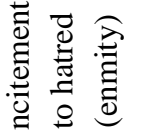 \\
\hline
\end{tabular}

4. Humiliation of the human dignity of a person (group of people) in connection with their social identity
4.1. 'Hyperidentity'
4.2. 'Enemy image'

5. Insulting the feelings of believers

In connection with the proposed classification, it is necessary to clarify a number of key points related to the generalization of the features of verbal extremism.

Firstly, threats to a person tied with expressions of disrespect and contempt for their religious views are considered extremist speech acts in the national law of the Council of Europe $(\mathrm{CoE})$ member states as well as in the $\mathrm{CoE}$ recommendations and in the practice of the 
https://doi.org/10.15405/ejsbs.296

eISSN: 2301-2218 / Corresponding Author: Nikishin Vladimir Dmitrievich

Selection \& Peer-review under responsibility of the Editors

European Court of Human Rights (ECHR). In Russian criminal law, in the researcher's opinion, the threat of violence should be considered as a qualifying feature, which is nowadays implemented in Art. 282 of the Criminal Code of the RF.

Secondly, propaganda (as an activity aimed at shaping a person's extremist views, conviction of their correctness and attractiveness, as well as an idea of the permissibility of extremist activities) is a generic concept, since it can be implemented through rationalisation, justification of extremist activities and calls for their execution, or only through rationalisation and /or justification as speech acts aimed at the formation of attitudes based on stereotypes. Skudin (2011) posits a different opinion, arguing that incitement to hatred is covered by such acts as calls for extremist activities and propaganda of superiority or inferiority. The spirit of the law suggests that the notion of 'propaganda' is used, first of all, in reference to rationalization of the need to carry out extremist actions, since the use of the term 'propaganda' as 'incitement to views, attitudes' would mean criminal prosecution for dissent, which is contrary to the rights to freedom of thought and freedom of religion guaranteed by the Constitution.

There are a number of features of propaganda discourse, such as:

- the existence of a subject of propaganda;

- the existence of an addressee of propaganda (certain / indefinite circle of persons);

- the existence of a set of relatively simple and consistent points (describing the desired state of affairs) and arguments;

- the existence of opposing evaluations of the desired situation and its negative alternatives;

- recurrent realization (multiple, intensive and systematic repetition of the same set of points or its fragments with identical or slightly modified argumentation);

- mass character (multiple texts produced within a certain period of time);

- a practical opportunity to disseminate information among multiple recipients (Baranov \& Parshin, 2017).

Thus, it is more correct to consider propaganda as a speech strategy that combines various speech acts.

As for the propaganda of 'Nazi memorabilia or symbols of extremist organizations' (Art. 20.3.1 of the Administrative Code of the RF), it can be defined as the speech act 'justification', that is, approval, praising an extremist organization; glorification of its representatives; expressing feelings of solidarity with the activities of an extremist organization, etc. 
Thirdly, 'incitement to hatred or enmity' as an independent speech act has not been singled out, since this concept is considered too vague. Kuznetsov and Olennikov (2014) and Kukushkina et al. (2011) who single out 'incitement to hatred or enmity' as a separate speech offense do not deny the statement that this notion is generic for other speech acts and intersects with other speech offenses. Paragraph 5 of the Russian Supreme Court ruling of June 28, 2011 No. 11 'On judicial practice in criminal cases on crimes of an extremist nature', interpreting the wording of the corpus delicti under Art. 282 of the Criminal Code of the RF ('Incitement to hatred or enmity, as well as humiliation of human dignity'), states that "Article 280 of the Criminal Code of the Russian Federation provides for liability only for public calls for extremist activity. The public dissemination of information rationalising the need to commit illegal actions against persons on the basis of race, nationality, religious affiliation, etc., or information justifying such activity, should qualify under Article 282 of the Criminal Code of the Russian Federation in the presence of other features of this corpus delicti”.

The researcher concurs with the causal approach to the interpretation of 'incitement to hatred or enmity' and considers this concept implemented through such extremist speech acts as 'rationalisation' and 'justification' of extremist activity. An expanded interpretation of the corpus delicti under Art. 282 of the Criminal Code of the RF poses risks to the establishment of censorship, violation the balance of freedom of speech and its limitations in order to protect the rights of others, public order and state integrity.

The metrological manuals developed by Russian law enforcement agencies (Gen. Pros's Office, 2008; Grimailo et al., 2010; Kukushkina et al., 2011; 2014; Venkova, 2011) as well as scientific and educational organizations (Kuznetsov \& Olennikov, 2014; Savinov, 2011; Zelenina \& Suslonov, 2009) and a substantial number of academic publications on forensic linguistics and anti-extremist law were analyzed in order to develop methodological approaches to forensic examination of extremist-terrorist discourse. It is worth highlighting that the manual for conducting a forensic psychological and linguistic examination of materials in cases related to countering extremism and terrorism developed by specialists from the Russian Federal Center for Forensic Examination at the Ministry of Justice of the Russian Federation (hereinafter - RFCFE) are among the metrological manuals developed by Russian law enforcement agencies. The researcher concurs with the rationale proposed by Kukushkina et al. (2011) who claim that there is a three-component semantic structure of an 'extremist' statement. Therefore, this idea has formed the basis for the suggested methodological approaches to the forensic linguistic examination of extremist-terrorist discourse.

The results summarizing the aforementioned manuals demonstrate the absence of a unified terminological system (apparatus) in methodologies proposed by the above authors / 
https://doi.org/10.15405/ejsbs.296

eISSN: 2301-2218 / Corresponding Author: Nikishin Vladimir Dmitrievich

Selection \& Peer-review under responsibility of the Editors

agencies. Moreover, the methodologies differ dramatically and sometimes suggest contrasting approaches to the detection of features of verbal extremism. This state of affairs clearly indicates a violation of the legally enshrined requirement for a unified scientific and methodological approach to forensic practice (according to Art. 11 of the Federal Law of May 31, 2001 No. 73-FZ 'On State Forensic Expert Activity in the RF).

An attempt was made to develop a unified methodological approach to forensic linguistic examination of extremist-terrorist discourse on the basis of expanding the conceptual understanding of the methodological approach to the examination of speech products of extremist discourse and generalizing the provisions of the abovementioned manuals of forensic examination of extremist materials.

Specialists of the Russian Federal Center for Forensic Examination at the Ministry of Justice of the Russian Federation consider an 'extremist' statement as a three-component semantic structure which comprise the following components: 1) subject-thematic (about whom / what and what exactly is said); 2) evaluative-expressive (how what is said (content) is evaluated, what emotions it evokes); 3) purpose (why it is said) (Kukushkin et al., 2011, p. 34). In other words, these components can be designated as: subject of speech, attitude, speech purpose.

It is extremely important to analyze all of the above-mentioned components as a whole, since ignoring at least one of them may lead to errors by the experts. The law does not prohibit speaking about something and does not censor any topics of speech (for example, on discussions of historical facts of interfaith conflicts, territorial disputes, etc.). What is prohibited are speech actions in which the topic of the speech product (the subject of speech, including the object of criminogenic speech aggression) is associated with a certain attitude of the author (positive (for example, admissible genocide) / negative (in this case, the need to change the situation is recognized)) and speech purpose (for example, to induce certain illegal actions) (Kukushkin et al., 2011; pp. 34-37). The evaluative-expressive component of the speech product (the attitude of the author) is a form of implementation of criminogenic speech aggression. It is important to note that the competence of a forensic expert presupposes the identification of the speech (communicative) purpose of the speech product, while the detection of the goal of the illegal act and its motive is the competence of the court.

The combination which includes a certain topic, a certain attitude of the author to the subject of speech and a certain speech purpose forms a forensic (criminalistic) diagnostic complex (CDC) of an extremist speech act, which has its own special (first of all, linguistic) features. 
https://doi.org/10.15405/ejsbs.296

eISSN: 2301-2218 / Corresponding Author: Nikishin Vladimir Dmitrievich

Selection \& Peer-review under responsibility of the Editors

\subsection{Forensic diagnostic complexes of extremist speech acts.}

Table 2. CDC 'calls for carrying out extremist activities'

\begin{tabular}{ll}
\hline $\begin{array}{l}\text { Speech product } \\
\text { component }\end{array}$ & \multicolumn{1}{c}{ Forensic (linguistic) features of the reference sample } \\
\hline $\begin{array}{l}\text { Topic (subject of } \\
\text { speech) }\end{array}$ & $\begin{array}{l}\text { 1. object of criminogenic aggression: } \\
\text { a) a group of people distinguished on the basis of social identity, or its } \\
\text { representative(s) } \\
\text { b) public order (public interests) } \\
\text { 2. unlawful extremist physical and / or speech actions that must be } \\
\text { committed by the recipient (addressee) in relation to paragraphs. 1a - 1b } \\
\text { attitude }\end{array}$ \\
Speech purpose \\
$\begin{array}{l}\text { recognition of the necessity of their commission } \\
\text { inducement of the recipient to commit the described / indicated extremist } \\
\text { actions }\end{array}$ \\
\hline
\end{tabular}

The concept of identity is complex and multifaceted and is usually understood as an awareness of a person's belonging to a community of people, which is meaningful for him/her (Nikishin \& Khurtaev, 2018).

The concept of 'public order', utilised in this paper, covers public relations that are the object of extremist-terrorist administrative offenses and crimes (with the exception of human and civil rights and freedoms), public security and public order, constitutional order and state security, peace and the safety of humanity.

Kuznetsov and Olennikov (2014) note that "Since some forms of extremist speech actions formally and meaningfully already include the linguistic constructions of a call to action, rationalisation or justification of the need for action ..., then it is obvious that there is no need to detect such logical grammatical constructions as 'calls to calls' or 'justification of justification"” (p. 19). The researcher partially agrees with this idea, as it is believed that, at first, grammatical constructions as 'calls to calls', 'calls to rationalisation', and 'calls to justification' can be used (for example, when propagandists call for disseminating their ideology or to convey the 'true' word of God). Secondly, there is no need to single out grammatical constructions such as 'rationalisation of rationalisation', 'rationalisation of justification', 'rationalisation of calls', 'rationalisation of humiliation', 'justification of justification', 'justification of rationalisation', 'justification of calls', or 'justification of humiliation' since these grammatical constructions are conditional and possible only theoretically. They are transformed into rationalisation / justification of specific extremist physical actions (and rationalisation / justification of humiliation is actually transformed into humiliation of human dignity) in the speech product. 
Table 3. CDC 'rationalisation of the need to carry out extremist activities'

\begin{tabular}{ll}
\hline $\begin{array}{c}\text { Speech product } \\
\text { component }\end{array}$ & \multicolumn{1}{c}{ Forensic (linguistic) features of the reference sample } \\
\hline $\begin{array}{l}\text { Topic (subject of } \\
\text { speech) }\end{array}$ & $\begin{array}{l}\text { 1. object of criminogenic aggression: } \\
\text { a) a group of people distinguished on the basis of social identity, or its } \\
\text { representative(s) } \\
\text { b) public order (public interests) }\end{array}$ \\
Attitude & $\begin{array}{l}\text { 2. unlawful extremist actions } \\
\text { a positive assesment of the described / indicated extremist actions, } \\
\text { recognition of their correctness and necessity } \\
\text { or }\end{array}$ \\
& $\begin{array}{l}\text { a promise to commit the described / indicated extremist actions with an } \\
\text { appeal to 'morally' support them (to pray for them, to make dual }{ }^{l} \text {, etc.) } \\
\text { convincing the recipient of the correctness and purposefulness of } \\
\text { committing extremist actions }\end{array}$ \\
\hline
\end{tabular}

It should be noted that the mere presentation of certain historical facts (including facts about religious wars, etc.) does not mean that there is rationalisation of the need to carry out extremist activities.

However, such statements, which meet the criterion of truth, can be introduced in an 'extremist' context, interchanging with fictional facts. Kuznetsov introduces the concept of 'factoid' to denote an opinion disguised as a fact considering the methodological aspects of forensic examination of extremist information materials (Kuznetsov \& Olennikov, 2014; pp. 96-101).

Table 4. CDC 'justification of the need to carry out extremist activities'

\begin{tabular}{|c|c|}
\hline $\begin{array}{l}\text { Speech product } \\
\text { component }\end{array}$ & Forensic (linguistic) features of the reference sample \\
\hline $\begin{array}{l}\text { Topic (subject of } \\
\text { speech) }\end{array}$ & $\begin{array}{l}\text { 1. object of criminogenic aggression: } \\
\text { a) a group of people distinguished on the basis of social identity, or its } \\
\text { representative(s) } \\
\text { b) public order (public interests) } \\
\text { 2. unlawful extremist actions }\end{array}$ \\
\hline Attitude & $\begin{array}{l}\text { a positive assessment of the described / indicated extremist actions } \\
\text { through their: }\end{array}$ \\
\hline & $-\quad$ approval \\
\hline & praise \\
\hline & glorification \\
\hline Speech purpose & $\begin{array}{l}-\quad \text { expressing feelings of belonging / solidarity, etc. } \\
\text { convincing the recipient of the admissibility / correctness / desirability / } \\
\text { necessity of committing extremist actions }\end{array}$ \\
\hline
\end{tabular}

\footnotetext{
${ }^{1} d u a($ Arabic دعاء) - a prayer.
} 
The speech action 'justification of the need to carry out extremist activities' presupposes, first of all, the statement that the generally accepted assessment of the subject of speech is incorrect, that actions prosecuted by law as extremist-terrorist actions are in fact acceptable and /or correct and /or desirable and /or necessary from the point of view of morality, religious customs, restoration of historical justice, etc.

According to note 1 to Art. 205.2 of the Criminal Code of the RF, public justification of terrorism is expressed in a public statement on the recognition of the ideology and practice of terrorism as being correct and requiring support.

Justification of the need to carry out extremist activities implies justification of not only modern, but also historical cases of violence and discrimination, publications and statements, throwing doubt on the generally recognized historical facts of violence and discrimination.

Table 5. CDC 'humiliation of the human dignity of a person (group of people) in connection with his/her social identity' ('hyper-identity')

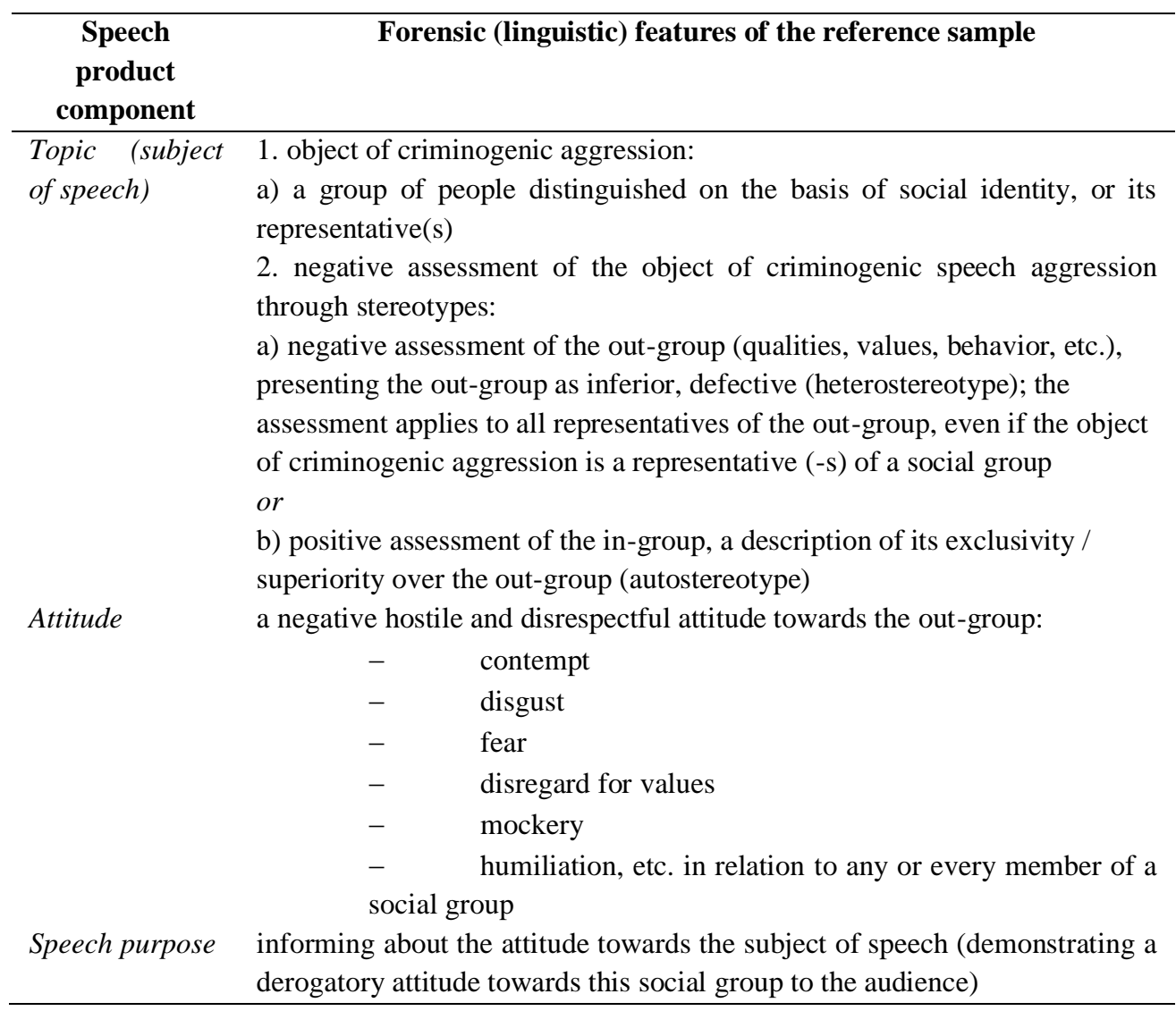


https://doi.org/10.15405/ejsbs.296

eISSN: 2301-2218 / Corresponding Author: Nikishin Vladimir Dmitrievich

Selection \& Peer-review under responsibility of the Editors

A stereotype is considered a cognitive scheme based on categorization, which is an awareness of the features of one's own community ('in-group', 'autostereotype') or other community ('out-group', 'heterostereotype'). In the framework of the forensic linguistic examination of (potentially) extremist-terrorist materials, it should be noted that an in-group is not necessarily described or mentioned in the speech product. In the case of the implementation of a heterostereotype, an in-group can be isolated as 'all persons not included in the out-group' ('we, not them'). Equivalents of the concepts of 'in-group' and 'out-group' are the concepts 'WE-group' and 'THEY-group' used by researchers of the European University (St. Petersburg) (Dubrovskiy et al., 2003).

In addition, in the case of the implementation of a heterostereotype, the assessment by the author of the in-group does not matte as there can be any type of assessment (including critical) or the assessment may be absent.

A negative assessment of the out-group can be expressed in statements about insufficient intelligence of representatives of the out-group, their cultural backwardness or lack of culture, etc.

It is important to note that statements that a particular religion is the only true religion, that its followers are chosen by God and have superiority over representatives of other confessions, etc. can be found in the Abrahamic religions i.e., Judaism, Christianity and Islam. The establishment of such statements in a speech product does not indicate the presence of 'extremist' meanings, since this subject of speech should be tied with a negative hostile and disrespectful attitude towards the out-group ('infidels', 'heathens', 'pagans') and the speech purpose of demonstrating to the audience a derogatory attitude towards this religious group.

In response to the court practice of recognizing religious materials as extremist only on the basis that they asserted the exclusivity of a religious group and the inferiority of other persons (for example, the Koran (translation) was recognized as being extremist (Sultanov, 2013), there were also some attempts to recognize the Bible as being extremist, etc.). In 2015, the Federal Law on Counteracting Extremism was supplemented with Article 3.1. titled "Features of the Application of the Legislation of the Russian Federation on Countering Extremist Activity in Relation to Religious Texts". This article establishes that the content and quotations from the Bible, Koran, Tanakh and Gandzhur cannot be recognized as extremist materials. 
Table 6. CDC 'humiliation of the human dignity of a person (group of people) in connection with his/her social identity' ('enemy image')

\begin{tabular}{ll}
\hline $\begin{array}{c}\text { Speech product } \\
\text { component }\end{array}$ & \multicolumn{1}{c}{ Forensic (linguistic) features of the reference sample } \\
\hline Topic (subject of & 1. object of criminogenic aggression: \\
speech) & a) a group of people distinguished on the basis of social identity, or its \\
representative(s) \\
2. negative assessment of the object of criminogenic speech aggression \\
through stereotypes: \\
a) attribution of the out-group hostility (hostile actions) in relation to the in- \\
group, as well as intentions to commit hostile actions in relation to the in- \\
group \\
or \\
b) explanation of the problems, calamities, troubles of the in-group by the \\
activity of the out-group \\
or \\
c) attribution of generalized negative characteristics to an out-group \\
(congenital or embedded in culture, including religious dogmas: negative \\
moral qualities, vices, etc.) \\
or \\
d) the transfer of negative characteristics of specific individuals (members \\
of the out-group) to the entire out-group, including attributing to all \\
representatives of the out-group the desire to follow the rules of conduct \\
(including archaic norms of religious law, ethnic customs, etc.), which are \\
illegal and (or) immoral from the author's point of view \\
negative hostile and disrespectful attitude towards the out-group: \\
a) fear \\
b) contempt \\
c) disregard for values \\
informing about the attitude towards the subject of speech (demonstrating to \\
the audience that the out-group is an enemy and source of harm)
\end{tabular}

The used notion of 'enemy image' in this case is formed from the concept of 'false identification', which Kroz and Ratinova (2005) define as "the formation and reinforcement of a negative ethnic stereotype, a negative image of a nation, race, religion, etc." and the concept of 'false attribution', which means "attribution of hostile actions and dangerous intentions to representatives of any nation, race, religion, etc.” (pp. 4 -15).

The meaning of a derogatory characteristic always contains some kind of humiliation of a person. The 'markers' of humiliation are indications of mental disability, professional incapacity, low social status and level of development, inability to think independently; zoosemantic metaphors indicating inferiority, lower level of development, etc. 
Table 7. CDC 'insulting the feelings of believers'

\begin{tabular}{|c|c|}
\hline $\begin{array}{l}\text { Speech product } \\
\text { component }\end{array}$ & Forensic (linguistic) features of the reference sample \\
\hline $\begin{array}{l}\text { Topic (subject of } \\
\text { speech) }\end{array}$ & $\begin{array}{l}\text { 1. object of criminogenic speech aggression: } \\
\text { a) images of personalities in relation to whom religious worship is carried } \\
\text { out; } \\
\text { b) religious symbols, emblems and signs; } \\
\text { c) revered images (icons etc.) and objects of worship; } \\
\text { d) religious dogmas, canons, rituals; } \\
\text { e) religious texts; } \\
\text { f) the image of religion / confession / other doctrine (including atheistic) } \\
\text { and their followers }\end{array}$ \\
\hline Attitude & $\begin{array}{l}\text { a negative attitude towards the subject of speech through the expression of: } \\
\text { a) contempt; } \\
\text { b) disgust; } \\
\text { c) neglect; } \\
\text { d) mockery; } \\
\text { e) desecration; } \\
\text { f) humiliation; } \\
\text { in an indecent (offensive) form }\end{array}$ \\
\hline Speech purpose & $\begin{array}{l}\text { informing about a negative disrespectful and contemptuous attitude towards } \\
\text { religion / confession / other doctrine (including atheistic) and their followers }\end{array}$ \\
\hline
\end{tabular}

Many researchers noted the imperfection of the Art. 148 of the Criminal Code of the RF ("Violation of the right to freedom of conscience and religion") with regard to legal technique, and also pointed out the unconstitutional, discriminatory nature of the use of the term 'believers' in the corpus delicti description, since it excludes the feelings of atheists from criminal legal protection ("Public actions expressing clear disrespect for society and committed in order to offend the religious feelings of believers") (Diakova \& Kadnikov, 2015; Fedotova, 2016; Ivanova, 2017; Shnitenkov, 2014).

The researcher believes that the concept of 'believers' in this case is subject to broad interpretation and defines atheists as persons who believe in the absence of God, i.e. the phrase "insulting the feelings of believers", in our opinion, is synonymous with the phrase 'insulting the feelings of citizens in connection with their attitude to religion', used in Part 6 of Art. 3 of the Federal Law on freedom of conscience and on religious associations. In this regard, the image of other doctrines tied with enjoying freedom of conscience (including atheistic doctrines) and their followers in the subject of speech in the forensic diagnostic complex titled 'insulting the feelings of believers' were also included.

The researcher opines that the CDC 'insulting the feelings of believers' and the CDC 'humiliation of the human dignity of a person (group of people) in connection with his/her social identity' differ, at least, in two ways. First, the subject of speech (the object of 
https://doi.org/10.15405/ejsbs.296

eISSN: 2301-2218 / Corresponding Author: Nikishin Vladimir Dmitrievich

Selection \& Peer-review under responsibility of the Editors

criminogenic speech aggression) is not a religious group (not followers of a particular religious doctrine), but the dogmas, symbols, images, etc. of this doctrine in the CDC 'insulting the feelings of believers'. Secondly, indecent (offensive) form of expression is a mandatory feature; otherwise, the act can be considered as blasphemy that is not legally punishable in the CDC 'insulting the feelings of believers'.

The researcher opines that special linguistic 'markers' of indecent (offensive) form are obscene, unquotable, vulgar, swearword, abusive, contemptuous, indecent, and dismissive lexemes.

It should be noted that real historical facts of military conflicts, ideological persecution, the use of violence, deportations, etc. can be used by delinquents in the argumentation strategies of rationalization or justification of the need to commit extremist-terrorist actions, humiliation of human dignity through the creation of an enemy image and other abovementioned speech acts.

The analysis of the components of forensic diagnostic complexes (the subject of speech, attitude and speech purpose) was carried out with the use of methods of subject-thematic, evaluative-expressive analysis and analysis of speech purposes, the methodological foundations of which were developed by specialists of the RFCFE (Kukushkina et al., 2011).

\section{Conclusion and Implications}

The comparison of the researched speech product with a corresponding forensic diagnostic complex enables a solution to a complex classification-diagnostic task in order to obtain a more comprehensive picture of the speech action, thereby providing law enforcement officers with forensic data in order to legally classify the action.

However, the study of the products of criminogenic speech actions, expressed in speech traces, is by no means limited to the activities of forensic experts. The study of speech actions as a representation of the actus reus of the offense, within the framework of their competence, is primarily carried out by law enforcement officers and judges.

The purpose of engaging a forensic linguist in proceedings of cases related to verbal extremism is to detect the communicative orientation of these criminogenic speech actions (semantics and pragmatics of the speech product). However, the need to appoint a forensic examiner arises in the case when there is ambiguity in the understanding of the meaning of the speech product by a law enforcement office and/or the court (including the presence of implicit meanings, manipulative techniques, etc. in the speech product). This is when an examination with the involvement of forensic (special) linguistic knowledge is needed. In other cases, legal 
https://doi.org/10.15405/ejsbs.296

eISSN: 2301-2218 / Corresponding Author: Nikishin Vladimir Dmitrievich

Selection \& Peer-review under responsibility of the Editors

qualification is possible on the basis of conducting forensic diagnostics by a law enforcement officer/judge without involving a 'knowledgeable' person (a forensic linguist').

Thus, the use of criminalistic (forensic) diagnostic complexes of extremist speech acts helps to ensure freedom of speech, the right to seek and receive information, since increasing the objectivity of the study of the circumstances of the case (based on clear criteria) allows for the protection of a person from illegal and unjustified prosecution if their actions are not dangerous to the public.

\section{Acknowledgements}

The reported study was funded by RFBR, project number 20-011-00190. The author(s) declare(s) that there is no conflict of interest.

\section{References}

Antonova, Y. A., Vesnina L. E., Voroshilova M. B., Zlokazov K. V., \& Tagil'ceva Y. R. (2014). Extremist Text and Destructive Personality. Ural State Pedagogical University Publ. House (In Russ.).

Austin, J. L. (1962). How to Do Things with Words. Oxford University Press.

Baranov, A. N., \& Parshin P. B. (2017). The Category of Propaganda in the Linguistic Examination of the Text. Theory and Practice of Forensic Science, 12(2), 53-65. https://doi.org/10.30764/1819-2785-2017-12-2-53-65

Diakova, S. V., \& Kadnikova, N. G. (2015). Commentary on the Criminal Code of the Russian Federation (scientific and practical, annotated). (3rd ed.). Yurisprudentsia. (In Russ.).

Dubrovskiy, D. V., Karpenko, O. V., \& Koltsova, E. Y. (2003). Hate Speech in the RussianLanguage Internet: Research Materials on the Recognition of the Hate Texts. European University Publ. (In Russ.)

Fedotova, Y. E. (2016). Insulting the religious feelings of believers: problems of application of Article 148 of the Criminal Code of the Russian Federation. Russian Law: Education. Practice Science, 4(94), 6466. (In Russ.).

General Prosecutor's Office of the Russian Federation. Research Institute for Strengthening Law and Order. (2008). On the Use of Expert Knowledge in Cases and Materials on the Incitement of National, Racial, and Religious Hatred. Methodological Recommendations. Prosecutor's Office Publ. (In Russ.).

Grimailo, E. A., \& Nazarova, T. V. (2010). Standard Methods of Forensic Linguistic Expertise: Methodology, Recommendations. In Y. M. Dildin, Y. M. (Ed.), Standard Expert Methods of Examination of Physical Evidence. Forensic Center under the Ministry of Internal Affairs Publ. (In Russ.).

Ivanova, T. E. (2017). Ratio of public actions that offend religious feelings of believers, with crimes of extremist orientation. Gaps in Russian Legislation, 4, 198-202 (In Russ.).

Kroz, M. V., \& Ratinova, N. A. (2005). Socio-psychological and legal aspects of xenophobia. Academia (In Russ.).

Kukushkina, O. V., Safonova, Y. A., \& Sekerazh, T. N. (2014). Methodology for Conducting a Forensic Psychological and Linguistic Examination of Materials in Cases Related to 
Countering Extremism and Terrorism. Russian Federal Center for Forensic Expertise under the Ministry of Justice of the Russian Federation Publ. (In Russ.).

Kukushkina, O. V., Safonova, Y. A., \& Sekerazh, T. N. (2011). Theoretical and Methodological Foundations of Forensic Psychological and Linguistic Examination of Texts in Cases Related to Countering Extremism. Russian Federation center for Forensic Expertise Publ. (In Russ.).

Kuznetsov, S. A., \& Olennikov, S. M. (2014). Expert research on cases of recognition of information materials as extremist: theoretical foundations and methodological guidance: (scientific and practical ed.). (2 $2^{\text {nd }}$ ed.). V. Ema Publ. (In Russ.).

Nikishin, V. D. (2019). Verbal Religious Extrimism. Legal Qualification. Expertise. Judicial Practice. Prospekt (In Russ.).

Nikishin, V. D., \& Khurtaev, K. I. (2018). Interethnic Student Clubs as a Mechanism for Educating All-Russian Civic Identity and Preventing Extremism in Educational Organizations of Higher and Secondary Vocational Education: A Methodological Guide. IPP "KUNA" Publ. (In Russ.).

Savinov, L. V. (2011). Research and Examination of Extremist Materials. SibAGS Publ. (In Russ.).

Searle, J. R. (1969). Speech Acts. Cambridge University Press

Shnitenkov, A. V. (2014). Insulting the religious feelings of believers: problems of legislative regulation of criminal liability. Sovremennoe pravo, 3, 108. (In Russ.).

Skudin, A. S. (2011). Legal Measures to Counter Extremism. Unpublished doctoral thesis, AllRussian Research Institute of the Ministry of Internal Affairs of Russia (In Russ.).

Sultanov, A. R. (2013). Recognition of a semantic translation of the Koran as extremist material and issues of due process. Advokat, 11, 5-13 (In Russ.).

Venkova, A. V. (2011). Technologies and methods for identifying and classifying content posted in information and communication networks as prohibited information (report on the agreement 15-01-42 / 06-11 of February 17, 2011). Ministry of Culture of the Russian Federation Publ. (In Russ.).

Zelenina, O. V., \& Suslonov, P. E. (2009). Methodology for Identifying Signs of Extremism. Procedural Examination (Forensic Expertise) of Audio, Video and Printed Materials: a Scientific and Practical Guide. Ural Law Institute of the Ministry of Internal Affairs of Russia (In Russ.). 